\title{
Accountability, Rule of Law and Fairness in Constituency Development Catalyst Fund (CDCF) Management in Vwawa Constituency, Tanzania
}

\author{
Frowin L. Mgani Carolyne I. Nombo Emanuel E. Chingonikaya \\ Department of Development Studies, College of Social Sciences and Humanities, Sokoine University of \\ Agriculture, P. O. Box, 3024, Morogoro, Tanzania
}

\begin{abstract}
This paper presents findings from a study which set forth to examine the governance of Constituency development Catalyst Fund. It focused on three pillars of governance which are; accountability, rule of law and fairness. The study was conducted in Vwawa constituency, in Mbozi District, Songwe Region in Tanzania. The study data were collected through semi-structure interviews, focus group discussions and (FGDs) and Observation. These were later transcribed and subsequently analyzed. The findings revealed that CDCF implementation was imbued with lack of accountability especially in publishing information of the expenditure of CDCF although villagers had chances to report all cases with fraudulent elements on CDCF and other funds. It was farther found that procurement process followed the required procedures, although in some circumstances it was influenced by either ward or constituency officers. Furthermore, it was found that the CDCF distribution was fair, however, in some cases, influenced by politicians especially the MP. Based on these findings, the study concludes that, the presence of well informed citizens may facilitate them to hold CDCF officers and other stakeholders accountable in any matter concerning the fund. Rules and regulations must be observed. Citizens must involve in decision making about CDCF activities. The practice done by some politicians in influencing the distribution of the funds is jeopardizing fairness in allocation of funds. All villages need the support from CDCF. The study recommends that, it is important to have well informed citizenly who can be able to hold officers and other stake holders accountable. It also recommends that, citizens should participate fully in decision making of CDCF activities. Lastly it recommends that, the distribution of the funds should not be influenced by the politicians.
\end{abstract}

Keywords: Governance, CDCF, Accountability, Rule of law, Fairness.

DOI: $10.7176 /$ RHSS/10-9-01

Publication date:May $31^{\text {st }} 2020$

\subsection{Introduction}

Governance in the recent past, have attracted voluminous publications which till now seem not to be agreeing on what exactly is and as the results there have emerged a number of perspectives on this concept. For example, Rosenau (2000) underscores that, governance mode of allocating standards while viewing government as operating mechanisms through which the allocation is accomplished. But for Hooghe and Marks, (2009) refer to the process of decision-making by different societal stakeholders on issues that affect their lives). However, to others it is perceived as the multidimensional term used to describe the interaction between citizens and their rulers and the way government can help or hinder their constituents' aspiration (Rothberg, 2002). While for Peter (2011), governance is about solving problems/ challenges faced by the communities collectively. As such, it means the interactions among structures, processes and traditions that determine how power and responsibilities are exercised, how decisions are made, and how citizens or other stakeholders have their say (Graham et al., 2003). Eventually, good governance is thus determined by the impact of the exercise of power on the quality of life enjoyed by its citizens (Shah, 2005). The concept of good governance it first appeared in the UN documents as well as in documents of World Bank (WB) in 1992 and International Monetary Fund (IMF) in 1996 (Katsamunska, 2016).

Good governance per World Bank (WB) referred to those neoliberals' reforms of the public management that the WB believed they could lead to great efficiency (Bevir, 2013). The concept of good governance has become a political and economic conditionality that is inseparable from debates about appropriate bilateral and multilateral efforts (Weiss, 2000).

Furthermore, governance can be understood the exercise of officials' power in the management of countries' resources in the effort of increasing and utilizing such resources for the betterment of life (Mdee and Thorle, 2016). Good Governance is enhanced when services delivered are based on citizens' preferences, and moving government closer to the people they intended to serve ensures greater accountability of the public sector (Shah, 2005). For WB, good governance constitutes several principles/pillars, mainly are 1. Participation, 2. Accountability,3. Transparency, 4. Efficiency and effectiveness, 5. Responsiveness, 7. Rule of law, 8 Fairness (Graham et al, 2003).

In the context of this paper good governance was measured in terms of three pillars which are accountability, rule of law and fairness. The three pillars were selected because they were the most observed and practiced in the study area. Similar studies were assessed by some scholars basing on some of the pillars of good governance 
(Reich, 2018; Ingram, 2017; Hood, 2010). As per Vasconcellos et al, (2018) accountability is a mutable term that adopts itself to each situation in which its mechanism are implemented. Accountability is what is owed to the people or the community at large, and can be brought of an essential a downward process (Hood, 2010).

Accountability as one of the key principle of good governance is needed in the management of public resources. It also involves people's interest, groups', civil societies', the courts, and the press interests (Johnston, 2012). Sanctions and compensations are the attributes of accountability (Fox, 2007). It involves ethics and politics as well as technical challenges (Reich, 2018). Accountability in this paper is conceptualized as the disclosure of revenue and expenditure of the funds by CDCF officials, imposition of sanctions and compensations in case of fraud or misuse of the funds. However, Accountability and rule of law are closely connected and that steps to promote one have the potential to reinforce initiatives that promote the other (Farrall, 2014).

The reliability of the rule of law requires rules to be known in advance, that they are actually enforced and applied consistently and fairly (IFAD, 1999). Rule of law refers to a principle of good governance in which all persons, institutions and entities, public and private, including state itself are accountable to laws that are publicly disseminated, equal enforced and independently adjudicated (Nollkaemper et al, 2008). In this paper the rule of law refers to rules and regulations concerning the CDCF management including aspects such as CDCF bank account, selecting suppliers/contractors, keeping bank slips and receipts of purchased materials to be used for development projects.

With regard to fairness, it is also among the principles of good governance. This principle is ensures that, all members of the community feel that they have a chance in it and do not feel excluded from the mainstream. This particularly applies to ensuring that views of minorities are taken into account and that the voices of the most vulnerable in society are also heard in decision making (Sheng, 2008). This requires mechanisms to ensure that all stakeholder groups have the opportunity to maintain or improve their well being. In the context of this paper fairness is referred to equity in distribution of the CDCF money in the villages development projects and who influences the location of funds in villages.

Constituency Development Funds (CDFs) are types of decentralized government funding mechanism that send funds from the central government to each constituency for expenditure on development projects intended to address particular local needs (Malya and Kessy, 2013). CDF policies have been practiced in different African, Asian and Carribian Countries. In Tanzania, CDF was introduced in 2009 under Constituency Development Catalyst fund (CDCF) Act No 16 of 2009 and was named as Constituency Development Catalyst Fund (CDCF). Under its Act, CDCF provide governance mechanism to ensure that, CDCF resources are used as intended to achieve their targeted objectives. CDF gives legislators a way to deliver essential goods and services to constituents and provide the opportunity of popular participation in development projects (Baskin, 2013).

The Commonwealth countries have principle guidelines for the operation of CDF, the principles highlight, transparence in selection and implementation of the projects, demand for accountability and maintain regular oversight. CDFs also should foster public learning through monitoring and evaluation of the projects (CPA, 2016). As per Article 10(1) of CDCF Act of 2009, at the constituencies' level CDCF is managed by CDC committee which has the maximum number of seven members, who are; Members of Parliament (MP) who is the Chairperson, DPLO (Secretary), two councilors, two WEOs in Tanzania mainland and in case of Zanzibar one Sheha, and one person nominated by the committee from among the active NGOs in the area, if any, this is in accordance with Article 10(1) of CDCF Act, 2009. Article 11 (2 \{a-d $\})$ the Constituency Development Catalyst Committee (CDC) general responsibilities are, to receive and scrutinize project proposals; approve projects proposals; compile quarterly reports, returns and reports of development projects undertaken in the constituency; and execute any other duty as may be necessary. According to Kimani (2009), CDF was hoped that it would enhance people's participation in decision making process, and promote transparence and accountability. This meant to promote good governance in the communities. For REPOA (2014) accountability means holding elected or appointed officials entrusted with public mandate and organization charged with managing public functions answerable for specific actions or activities to the citizens from whom they derive their authority (Mallya and Kessy, 2013).

CDCF governance in Tanzania is about the extent to which members of the CDC committee, officials and constituents adhere to good governance criteria of rule of law, accountability, participation, transparency, equity, efficiency, responsiveness. The CDC committee is the main organ of CDCF, it is responsible and answerable for all activities of CDCF in constituencies, and due to this CDC committees necessitate abiding with good governance pillars in its functions. To achieve accountability of the fund, there is a need to have appropriated information to overcome problems in the community. Literature confirms that information dissemination is one of the principle agents to accountability of appointed and elected officials (Reich, 2018; Kosack and Fung, 2014; Fox, 2007; Ball, 2009).

The proper management of CDCF is inseparable from the pillars of governance like Accountability, rule of law and fairness under which CDCF, Act, 2009 sets parameters on how to manage the CDCF in all electoral constituencies in Tanzania including Vwawa constituency. However, there is insufficient information on how $\mathrm{CDCF}$, Act parameters were disseminated in Vwawa constituency to facilitate accountability, rule of law and 
fairness in CDCF management. It is assumed that combination of these elements of good governance can create conducive atmosphere for the conduct of government business that is pro-people, and one that is likely to accelerate the development process (Mallya and Kessy, 2013). This paper therefore reports the findings of study that aimed at examining the accountability, rule of law and fairness in CDCF in Vwawa Constituency, Tanzania. Specifically, the study examined the accountability of CDCF, rule of law in CDCF projects implementation and fairness in CDCF distribution.

\subsection{Theoretical Framework}

The study was guided by Decentralization Theory as propounded by Alexis Tocquesville in 1820s. The theory considers "transfer of responsibilities, resources, or authority from higher to lower level of government as the best practice and imperative in discharge of public affairs" (Fallet, 2005). Elaborating it further Barnet (1999), argue that decentralization the transfer of authority, responsibility, and accountability from central to local government. For Kisumbe et al (2014) decentralization is a vehicle of reforming governance with the focus to transfer some political, financial, and administrative power from central government to local government and can also be driven by desire to move services closer to the people.

Nevertheless, for the World Bank (2004) decentralization encourages the desire to bring politicians and policy makers closer to clients and to make services more effective, although success depends on how decentralization affects relationships of accountability and enhances fairness. Thus, taken as a political strategy (Kisambe et al, (2014). Decentralization is expected to boost public sector efficiency, as well as transparency, participation and accountability in service delivery and policy making (Mello, 2000). The assumption is that decentralization works by enhancing citizens' voice and in a way that leads to improved social services delivery. The mode of citizens' participation can largely be categorized into vote and voice (Kauzya, 2007).

In Tanzania, decentralization is part of the efforts made by the government to improve social services delivery at local level (Molel, 2010). Decentralization was adopted with the aim of bringing government closer to the citizens because, in a system in which decisions about resources allocation and services delivery are supposed to be more responsive to local needs, usually people's directly involved in decision making or indirectly influencing those decisions is paramount (Massoi and Norman, 2009). In the context of this paper, the Decentralization Theory was used to establish how responsibility, resources and authority from the central government were transferred to constituencies and ultimately to the citizens. In this perspective the lower level of the government includes; CDC committee, WEOs, WDC, VEOs and ordinary citizens.

\subsection{Conceptual Framework}

Accountability and rule of law are closely connected; one enforces initiatives that are promoted by the other. Accountability is subjected to law in the sense that, one can be answerable basing on rules and regulations set in the rule of law. Sanction and compensations in accountability depend on the rules and regulation. Officers who involved in the allocation of CDCF are also accountable to whatever happens on the process of distribution. All of these work together for the purpose of good management of the CDCF. 


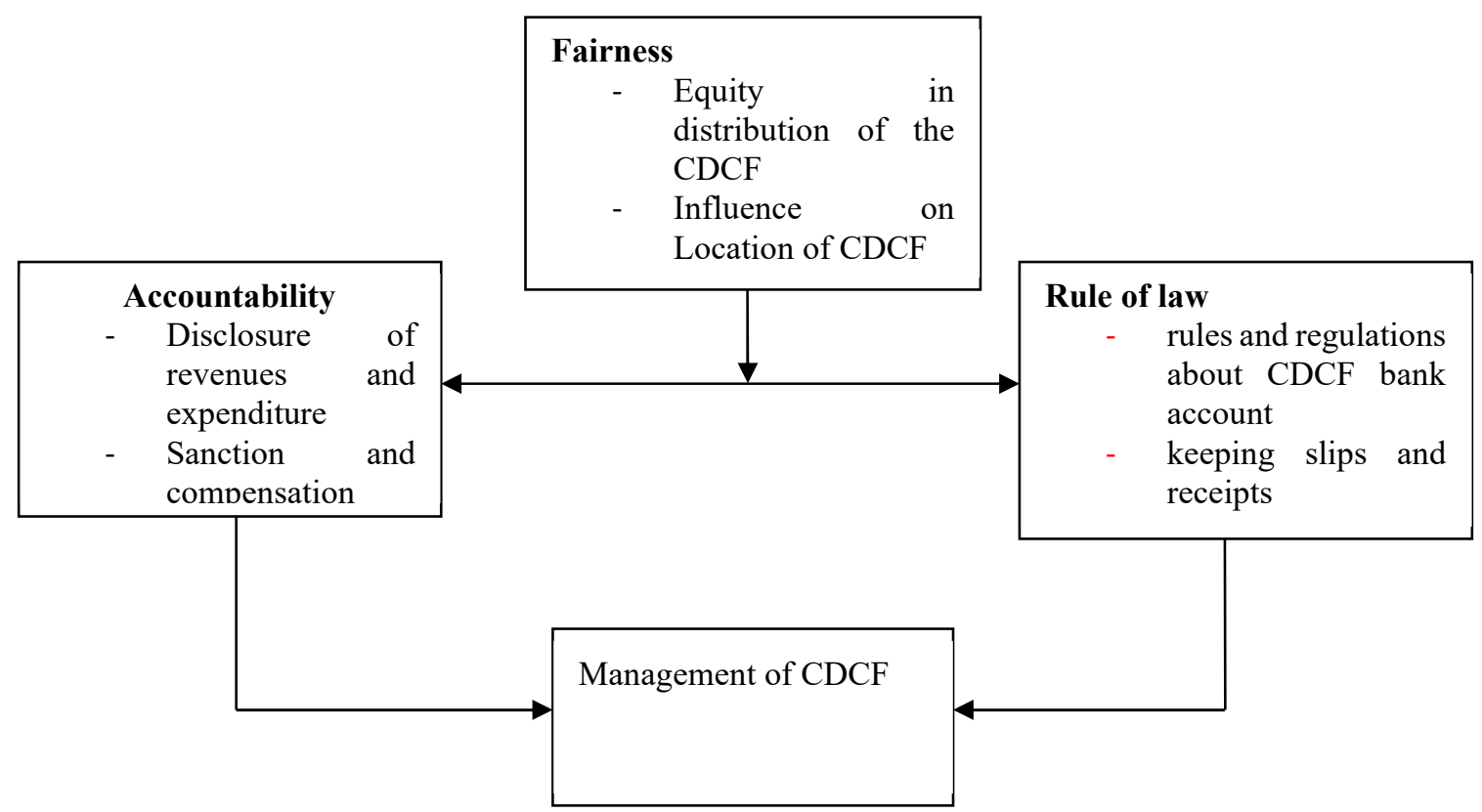

Figure 1 Conceptual Framework of the Paper

\subsection{Study Methodology}

The study was conducted in Vwawa Constituency in Mbozi District, Songwe Region. Vwawa Constituency is one among 265 electoral constituencies in Tanzania and is composed of 18 wards. The major economic activities in Vwawa are farming and livestock keeping. Vwawa was purposely selected because it is one of the 26 new electoral constituencies since 2015, the reason of selecting the new ones is to examine how the CDCF was managed in these newly constituencies. Simple random sampling was used to obtain Vwawa constituency out of 26 newly constituencies.

The study utilized qualitative research approach within which case study research design was chosen as most appropriate to guide the study. The study's targeted population constituted Village Chairpersons (VC) and Hamlet Chairpersons (HC), Extension Officers (EOs), Village Development Committee (VDC) members and ordinary citizens. Data collection was by means of Key informant Interview focused group discussion (FGD), interviews and observation. Observation focused on observing practical projects and CDCF disbursement provided in form of materials.

Data were collected from purposively selected 17 key informants from District Councils, wards and villages. The key informants included district planning officer (DPLO), ward executive officers (WEOs) and village executive officers (VEOs) who provided information on CDCF implementation in their administrative areas. To allow flexibility without affecting focus, semi-structured interviews were used with key informants. For Creswell (2012), interviews provide useful information when you cannot directly observe participants and they permit participation to describe detailed personal information. Data were also generated from focus Group Discussions (FGDs) involving ten groups comprised of 5 to 9 participants. The FGDs were conducted in village councils found in ten villages namely Mbewe, Ndolezi, Sakamwela, Hanseketwa, Senjele, Namlonga, Chimbuya, Isandula, Lumbila and Wellu II. In each selected village, a focused group discussion (FGD) was carried in small groups consisting of men and women. There were categories of FGD, the first category composed of ordinary citizens and the other consisted of village development committee members (VDC). The participants were purposively selected during an extra - ordinary villagers meeting called by the VEOs. The FGDs were guided by a well structured themes and topics for discussion.

Data were thematically analyzed and conclusions were drawn based on various themes identified from them. As Creswell (2012) puts it, the use of themes is another way of analyzing data because themes are similar codes aggregated together to form a major idea in the data base. The data recorded using a tape recorder were first transcribed. After transcription, different categories were created and labeled (open code process). The categories with the same codes were connected in a logical and meaningful way. Then the single core category was identified. Thereafter, the case studies sets in form of quantitative interpretations and descriptions were documented. This approach is collectively termed as content analysis. 


\subsection{Findings and Discussion}

CDCF governance in this section is viewed basing on some pillars of governance as per World Bank and IMF perspectives. It is based on the pillars of accountability; rule of law and fairness. Focusing on accountability, it considers the answerability of elected and appointed officials to display CDCF reports for the constituents to get information. It further based on the steps taken in case CDCF is confronted with fraud. While the rule of law focus on some rules and regulations observed during CDCF implementation, and lastly equity: specifically focus on fair distribution of CDCF in supporting development projects in villages.

\subsection{Accountability of CDCF}

In this sub-section, the study focused on village officers disclosing of CDCF report on the village public noticeboard and answerability in case of fraud or misuse of CDCF. The findings show that, in some villages, like Mbewe, Well II, Ruanda and Ndolezi there were notice-board in at the government office, while the rest six villages namely; Namlonga, Sakamwela, Lumbila, Ihanda, Hanseketwa and Senjele there were no public notice boards at the government office where reports could be posted (Table 3.1). This was revealed by one of the Key informant of Hanseketwa village who viewed that: "There is no notice-board at our village government office. The village assembly meetings always provide the report of expenditure of the funds used for the projects." (Key Informant 1: April, 2017).

The quotation here indicates that some village officers did not notice the importance of public notice-board to be placed at the government offices; this is why there were no 'public notice-board' in some villages. However, even in the villages where there were public notice boards, still there are village officer did not display CDCF reports on the public 'notice-boards' as the means of showing accountability. This implies that, there were no habits of displaying the report of the expenditure at the 'public notice board' in spite of the fact that citizens have the right to see the reports of revenue and expenditure is posted on the village public notice-boards. The only way that villagers got the report was through village assembly, and this reached to those who were participating in the village meetings. Otherwise, there was no access to information about CDCF report and other issues that belong to the villages.

Disclosing information in the public notice-board is one of the means of "disseminating information", and thus facilitates citizens to hold their representatives accountable. Kabyemela (2017) found that, most of the activities undertaken by the village governments in Tanzania were not disclosed to the citizens. For Chaligha (2014), government officials can disclose information to citizens through a number of information outlets (public notice boards, public meetings, newspapers, radio, television, the internet and so on). Fung and Kosack (2014) argued that, in order for citizens to express their preferences and hold their leaders accountable for realizing those preferences: they require access to the widest possible range of information. As Gaventa and McGee, (2011) and, Reich, (2018) argued, access to information can contribute to accountability of officials and increased transparency in decision making and can facilitated greater accountability to citizens.

The literatures mentioned above do not support the findings on the aspect of accountability of the funds particularly on disclosing revenue and expenditure of the fund. Weakness of the village officers and ignorance of most of constituents' members about regulations with regard to public expenditure was the main case. Reports for CDCF expenditure were supposed to be displayed for the sake of citizens to be informed so as to enhance accountability to officials and all stakeholders.

Table 1: Villages with and those without Public notice-board

\begin{tabular}{lllc}
\hline Sn & Villages without public notice boards & Sn & Villages with public notice boards \\
\hline 1 & Namlonga & 1 & Mbewe \\
2 & Sakamwela & 2 & Wellu II \\
3 & Lumbila & 3 & Ruanda \\
4 & Ihanda & 4 & Ndolezi \\
5 & Hanseketwa & 5 & NA \\
6 & Senjele & 6 & NA \\
\hline
\end{tabular}

\section{Source: Field data}

In case of fraud of the CDCF, village/ward officers gave directives on where to report such cases. The next process was the investigation of the allegations to identify the accused ones. This was made clear by one of the FGD of Lumbila village that;

...citizens were given instructions where to send the report if they thought there was elements of fraud on CDCF. In case of fraud the village government council prepares the report to be sent to the public village meeting. Once the report is delivered to the village meeting and discovers the elements of fraud, then investigation is done to identify who are involved in misuse of the funds, whether providers or suppliers or receivers of funds/materials in the village (FGD: May, 2017).

The implication is that, CDCF as a funding mechanism from central government is also subjected to fraud. Citizens were therefore given instructions on how to deal with those who misuse funds and hence promote 
accountability among providers and users of funds at the village level. Decentralization Theory emphasizes on the transfer of responsibilities, resources and authority from the central government to the ordinary citizens. In this aspect the theory concurs with the findings, due to the facts that, ordinary citizens were given the authority and responsibility to deal with wrong doers in case there were anyone accused of misusing the funds. This facilitates accountability to alls CDCF stakeholders. Open meetings attended by key stakeholders, may provide mechanism for asserting procedural and allowing public review and criticism thereby advancing accountability (Hood, 2007). When citizens are empowered, whether on their own or in alliance with others, their demand for accountability can make politicians or officials respond in ways that compensate for weaknesses elsewhere in the service delivery chain (World Bank, 2004). Officers, citizens and other stakeholders require being answerable to the acts performed during the process of implementation of the CDCF supported projects. Sanctions and compensation are vital in accountability arena; one actor can demand explanations or justifications of another actor for its actions and punish the second actor on the basis of its explanations (Reich, 2018).

\subsection{Rule of law on CDCF projects implementation}

The study findings in sub-section: on one hand are based on regulations in accordance to CDCF Act, 2009 with regard to $\mathrm{CDCF}$ bank account. On the other hand, focus on the rules and regulations concerning receipts of buying equipments/materials together with slips for banking transaction and selection of the suppliers/contractors of the CDCF supported projects. The findings show that, villages did not open a special bank account for CDCF; instead the funds were deposited in village account. During the FGDs, it was found that once the funds were provided to villages were kept in village bank account because there was no bank account for CDCF at the village level, and after a while the fund was used to support projects. In one of the FGDs of Sakamela Village viewed that; ...the $C D C F$ is deposited in the village bank account, and the supplier/contractor is given a cheque that has been approved by village council (FGD: April, 2017). While the other FGDs of Well II village was in the view that; ...the lists of the projects selected are sent to the district council. Then the District Planning Officer deposits money in a particular village bank account (FGD: May, 2017).

The quotes imply that, it was not necessary for the village to have a special bank account for CDCF. Only village development account was enough, any fund for development could be deposited there. In some circumstances CDCF was sent in form of materials like cement, iron sheets and iron bars for constructions. Under such circumstances there was no need of bank account because the money was already used to purchase materials.

However, in case when CDCF was sent in form of cash, that was deposited in a village account: the study found that, the receipts for purchasing materials for construction and receipts for banking transactions and payments were kept ready for auditing. This was evident from the disclosure of one of the Key informant from Chimbuya village who narrated that; "In our village there are files that keep the receipts and other documents including CDCF receipts and documents." (Key Informant, 14 ${ }^{\text {th }}$ April 2017). This implies that rules and regulations were observed with regard to the use of $\mathrm{CDCF}$, keeping receipts is good sign of accountability. With reference to the CDCF Act of 2009 article 17 (1), it is stated that, the council shall compile and maintain a record showing all receipts and disbursements on a monthly basis in respect of every project under this Ac

In case of selection of the suppliers/contractors of CDCF projects in particular; the findings show that, the suppliers or contractors were selected by either ward officials at ward level if the projects were for the ward and at the village if the projects were at the village and sometimes suppliers were selected directly by the CDC committee. Decentralization Theory highlights among others matter, the transfer of authority from the central government to the constituency and ultimately to the citizens. Contrary to this, the findings show that ordinary citizens in the study area were not given full authority to decide about suppliers / contractors. This implies that ordinary citizens were hardly included in the selection of the suppliers / contractors something that can lead to biasness and encourage nepotism in the selection of the suppliers.

CDCF were provided either in form of materials or in form of cash. For the CDCF that was provided in form of materials the process of obtaining suppliers was done through several steps, which are advertizing the tender, checking qualified suppliers, choosing the qualified supplier and last the supplier should start providing services. These are normal procedures of tendering in the government of United Republic of Tanzania. However, the findings revealed that, WEO, VEO and MP had influence in the selection of the suppliers. These officials direct where to buy materials by specifying a certain shop. This was revealed in one of the FGDs of Lumbila village;

...the village is given the procedures of getting materials by CDCF committee. The letter is brought with the proposed suppliers. However the letter comes with precaution from either VEO or WEO or MP that, the materials should be bought in a particular shop, otherwise their request will be disapproved. (FGD: May, 2017).

This indicates that, some good government official did not follow procedures in accordance to Public Procurement Act of 2004. On one hand, they might have been done to safeguard the community interests since constituents are hardly informed about the fund. On the other hand they might have been done for their selfinterests and not community interests as such. In some circumstances materials were brought by the CDC 
committee and supplied them to the villages. This means that there was no quotation process as per rules and regulations of public procurement Act, 2004. The URT (2012) emphasizes that, in liberalized markets potentials contractors should be allowed to compete in a transparent and fairly managed environment that allows each eligible contractor an opportunity to participate in public procurement contract offerings. This was different from the findings, and it is contrary to the rule of law, because in most cases the regulations were violated. This kind of practices was jeopardizing rule of law and accountability as important pillars of governance. It was also contrary to decentralization theory which emphasizes on enhancing citizen voice towards improving social services.

\subsection{Fairness in CDCF distribution}

The study here dealt with equity in the distribution of CDCF money in village communities and how some politicians influenced the distribution within the constituency. With regard to equity on CDCF allocation, the findings show that, some respondents were of the opinion that, CDCF should be distributed to all villages in each financial year because all villages needed the support. This was evident from one of a FGDs of Hanseketwa that; ...each village has its development projects that have to be fulfilled. CDCF should be provided to all villages in each financial year so as to bring equality in all villages and avoid lamentations from some villages and provide development to all. (FGDs: April, 2017).

This indicates that, some constituents were eager to see that the fund is provided to each village in each financial year to facilitate development projects. However, considering the number of villages in the constituencies the fund provided was not enough to be distributed to all projects in the villages. The best way is to allocate CDCF was basing on the preferences (Table, 3.3). In one hand, even if the amount of CDCF budgeted in the constituency could be in some hundreds million TSH; still not all projects require similar support of CDCF; some projects need more support than others. The limitation of budget allocated to constituencies lead to uneven distribution of fund to support development projects in all villages. Tsubra (2013) found that, there is unequal allocation of the funds to the constituencies due to the limited budget of $\mathrm{CDCF}$.

According to CDC Committee of Vwawa Constituency in FY 2016/2017, the constituency received 43 million Tanzanian shillings for supporting the projects in all villages of the constituency. If this amount could be distributed equally to all villages without considering preferences, very little amount could be provided and but could not be enough even for buying some materials that can fulfill the needs of a particular projects, at the particular moment the best way was the funds to be distributed fairy and in accordance to preferences. The argument based on priorities is good; it can show the essence of contribution of the CDCF in development projects.

Politicians like MP and Ward Councilors are usually involved in decision making and the implementation of the CDCF. For some politicians their involvement on CDCF influenced the distribution of the funds among wards and villages for political gain. It happened because the MP as a chairperson of CDC Committee influenced decisions of the meetings for his/her interest depending on the promises he/she made during electoral campaigns. This was revealed by one of the officers at the district level, who narrated that;

"The MP as a chairperson of the committee has the power to influence the decisions about the fund.

She/he may have his/her preferred projects to be supported. Yet, the influence of ward cancellers is in the ward level when they are with WEOs. They check where they can get more support" (Key Informant17: June, 2017).

This can be interpreted that, politicians influenced the decisions because of their promises they make during electoral campaign or political rallies. In some circumstances CDC committee members had little influence during decision making of CDCF as long as the meeting is headed by the MP as a chairperson of the committee. As per Tsubra (2014) some politicians like MPs can use the CDCF for political gain such as buying voters especially the illiterate ones who may think that the funds come from the MP's pocket.

It is always understood that MPs are the ones who solicit projects from the community when mobilizing community projects or addressing political rallies (REPOA, 2014). Some politicians do all these to fulfill what they promised; otherwise they have to be challenged for unfulfilled promises at the end of the term of their leadership especially when they want next term or for their political parties. Here it can be argued that, the basis of their influence is self interest and that of their parties. 


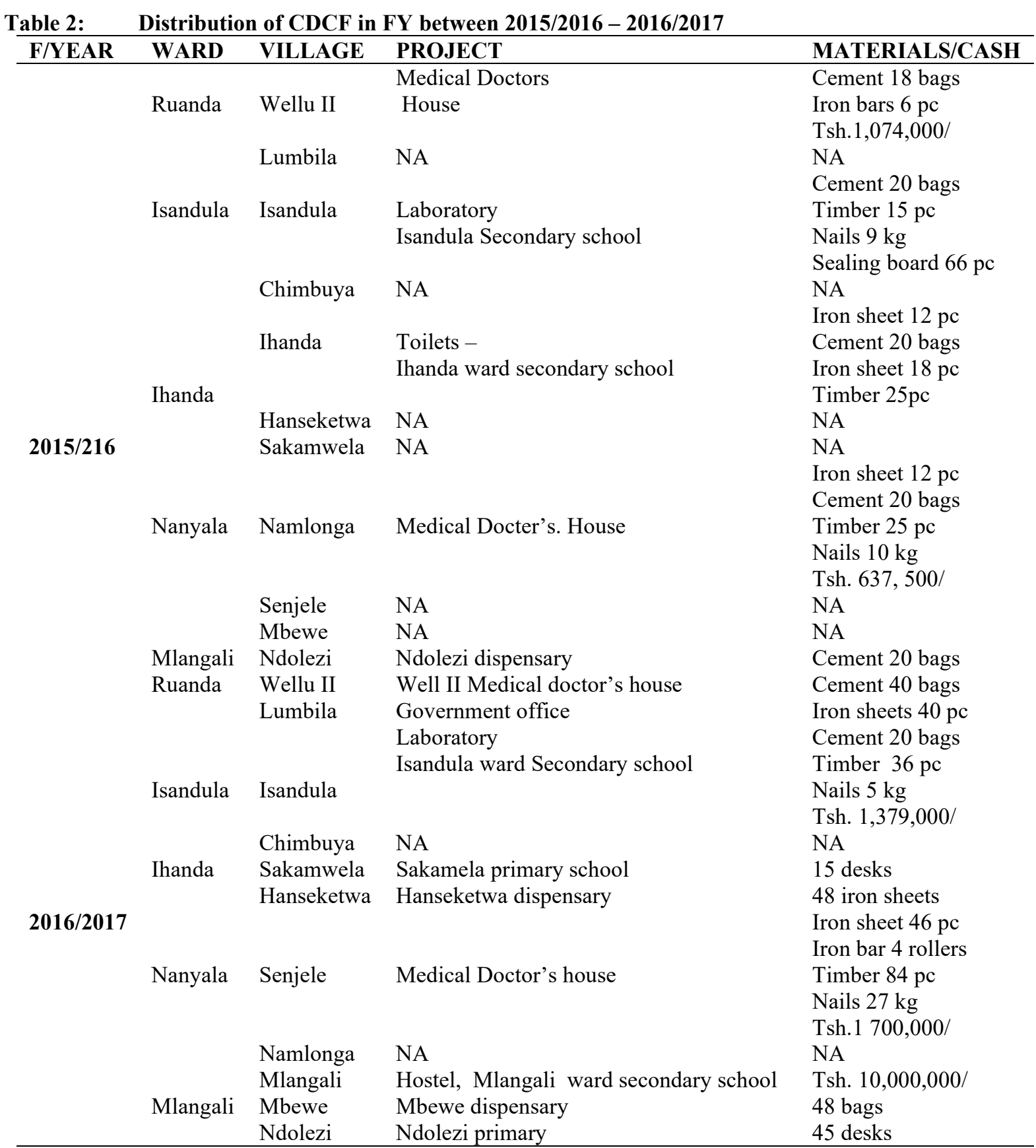

Source: Vwawa constituency- CDC Committee, 2017

\subsection{Conclusion and Recommendations \\ 4.1 Conclusion}

The study concludes that, ordinary citizens have the right to access information and to be informed about what is going on in the implementation of the projects and the expenditure of the funds. Access to information facilitates accountability among the stakeholders. Presence of well informed citizens may hold CDCF officers accountable in any matter concerning with fund Disclosure of the revenue and expenditure of the CDCF proves presence of accountability among CDCF officers.

The study also concludes that, the observation of rules and regulations is salient to all CDCF officers and the citizens as the beneficiaries. Ordinary citizens must be involved in decision making to whatever concerned with the CDCF activities. Exclusion of the ordinary citizens in decision making is to act contrary to the rules and regulations and it is contrary to decentralization policy of the country. It further concludes that, the fairness in the distribution of CDCF is encouraging, because the needs differ from one village/ward to another. The practice done by some politicians in influencing the distribution of funds is jeopardizing fairness as one of the pillars of good governance. 


\subsection{Recommendations}

The study recommends that, there is need to have well informed citizenly and other stakeholders about the fund, for the sake of holding officers and other stakeholders accountable in case of anything wrong about the use of the CDCF money. It also recommends that, citizens as the beneficiaries of the funds should not be excluded in decision making in some aspects like selecting suppliers / contractors. Instead they should be given the chance to participate fully. This is to emphasize the decentralization theory. Lastly, it was recommends that, the distribution of the fund should not be influenced by the politicians. Any kind of influence from a leader or an individual should be discouraged seriously.

\section{References}

Baskin, M. and Samrat, L. H. and Ashe, R. (2010). Constituency Development Funds as a Tool of Decentralization Development. In: The workshop: The Role of Parliamentarians in Facilitating Grassroots Projects. State University of New York Centre for International Development. 10-19 September 2010 New York. 33. Pp.

Bevir, M. (2013). A Theory of Governance. Global, Area, and International Archive. University of California Press. Loss Angeles. 263 pp.

Callahan, K (2007). Elements of Effective Governance. Measurements, Accountability and Participation. CRC Press, Taylor and Francis Group. 2007. New York.

Callahan, K. (2007). Elements of Effective Governance. Measurements, Accountability and Participation. CRC Press, Taylor and Francis Group. 2007. New York. 360 pp.

Chaligha, E. A. (2014) Transparency and Accountability in Local Government in Tanzania. Policy Forum and REPOA. Dar es Salaam. 44 pp.

Cohen, L. Manion, L., Morrison, K. (2007). Research Methods in Education. Routledge, New York. 638. pp.

Commonwealth Parliamentary Association (CPA), (2016). Handbook on Constituency Development Funds. Principles and Tools for Parliamentarians. The Commonwealth Parliamentary Association, London. 66 pp.

Creswell W. J. (2012). Research, Conducting and Evaluating Quantitative and Qualitative Research. University of Nebraska. Lincoln. 650 pp.

Czempied, O. E. (2000). Governance and Democratization. In Governance without Government: Orders and Change in World Politics. Cambridge University Press. Cambridge. 173 pp.

Eriksen, S. I. (1994). Introduction Between a Rock and a Hard Place? Development Planning in Tanzania Local Governments. Third world Planning Review. 19(3): 251 - 269).

Farrall M. J. (2014). Rules of Accountability or Rule of Law? Regulating the UN Security Council's Accountability Deficit. Journal of Conflict and Security Law. 19 (3): 389 - 408.

Fox, J (2007) The Uncertain Relationship between Transparency and Accountability. Development Practices. 17 (4-5): $663-671$.

Gaventa, J. (2002). Legal and Policy Frameworks of Citizens Participation in Local Government in East Africa, A Regional Report. Long Link. Institute of Development Studies, University of Sussex. 43 pp.

Gaventa, J and McGee, R (2011). Shifting Power? Assessing the Impact of Transparency and Accountability Initiatives. IDS working Paper. O: 383. 1- 39.

Graham, J., Amos, B., Plumptre, I. (2003). Principle for Good governance in $21^{\text {st }}$ Century. Policy Brief 15. Institute on Governance. Ottawa. 342 pp.

Grindle, M. (2010) Good Governance: The Inflation of an Idea. HKS Fuculty Reseach Working Paper Series, RWP 10-023, John F. Kennedy School of Government. Harvard University. 22 pp.

Hooghe, L and Marks, G. (2009). Does efficiency Shape the territorial structure of Government. Annual Review Political Science 12: $225-241$.

Hood, C. (2010). Accountability and transparency Siamese Twins, Matching Parts, Awkward couple. Western European Politics. 33 (5): 989 - 1009.

Ingram, A. (2017). Transparency for Results Testing a model of Performance, Management in Open Government Initiatives. International Journal of Public Administration. https//doi.org/10.1080/01900692.2017

Internation Agriculture Fund for Agricultural Development (IFAD) (1999). Good Governance: An Overview. Executive Board - Sixty seventh Session Rome, 8-9 September 1999. 214 pp.

Johnston, M. (2012). Good Governance, Rule of Law, Transparency and Accountability. Department of Political Science. Colgate University. $157 \mathrm{pp}$.

Kabyemela, M. (2017). Democratization and Public Accountability at the Grassroots in Tanzania. African Studies Quarterly 17 (1): 44 - 60.

Katsamunska, P. (2016). The Concept of Governance and Public Governance Theories. Economic Alternatives 2: $133-141$.

Kothari, C.R. (2009). Research Methodology, Methods and Techniques. New Age International (P) Ltd. New Delhi. $401 \mathrm{pp}$. 
Malya, T .E. and Kessy, L. F. (2013). Governance, Local Governments and the Constituency Development Catalyst Fund in Tanzania. Journal of Poverty Alleviation and International Development 4 (2): 19-54.

Mdee, A. and Thorley, L. (2016). Good Governance, Local Government, Accountability and Services Delivery in Tanzania. Exploring the Contest for Creating A Local Governance Performance Index. Economic and Social Research Council. Mzumbe University. 21 pp.

Nollkaemper, A., Wouter, J and Nicolas Hachez, N. (2008). Accountability and Rule of law at International Level. Amsterdam Centre for International Law. University of Amsterdam. 13 pp.

Osborne, D and Gaebler, T. (1992) Reinventing Government: How the Entrepreneurial Spirit is Transforming the Public Sector. Addison - Wesley.

Otieno, G. O., Nyadwaki, M. J., Momanyi, G. (2015), Evaluation of the Management and Utilization of Consitituency Development Fund on Education Development in Gem Constituency, Siaya District,Kenya. Journal of Research \& Method in Education.5 (2): 27-45.

Oyugi W.O. (2000). Decentralization and Citizens Participations in Africa. Regional Development Dualogue. United Nations Center for Regional Development. Nagoya 21 (1).

Peter, G. (2011). Governance as a Political Theory. Critical Policy Studies 5 (1): 63 - 72

Ramesh, R. Ijhas, M. M and Dickwella, R. (2013). Accountability, Transparency and Corruption in Decentralized Governance: A Case of Local Government in Sirlanka. Proceeding of the Third International Symposium. SEUSL: 6-7 July 2013. Oluvil. Sir Lanka Oluvil. 62 pp.

Reich, R. M. (2018) The Role of Transparency and Accountability in the Governance of Global Health PublicPrivate Partnerships. Health System and Reform. 00: 1-10.

REPOA, (2014). Review of the Governance Effectiveness of the CDCF in Tanzania. REPOA. Dar es Salaam. 44 pp.

Rosenau, J. (2000). Governance, Order, and Change in World Politics. Cambridge University Press. Cambridge. $29 \mathrm{pp}$.

Rothberg, R. I. (2002). The New Nature of Nation -state Failure. Washington Quarterly 25 (3): 85-96.

Ruggie G. J.(2014) “Global Governance Theory” Lesson form Bussiness and Human Rights.Global Governance. 20 (1). 5-17.

Shah, A. (ed) (2005) Public Service Delivery: Public Sector Governance and Accountability Siries, Public Services Delivery. The World Bank. New York. 219 pp.

Sheng, Y.K, (2008). What is Good Governance? United Nations Economic and Social Commission for Asia and the Pacific. Bangkok. 3 pp.

Stoker, G. (1998). Governance as Theory: Five Propositions. Blackwell Publisher. Oxford. 12 pp.

Tsubura, M. (2014) Accountability and Clientism in Dominant party Politics. The case of Constituency Development Fund in Tanzania. Doctoral Thesis (PhD), University of Sussex. Brighton. 210 pp.

United Nations Development Partner (UNDP) (1997). Re-conceptualizing Governance. Discussion Paper No.2. New York. UNDP.

United Republic of Tanzania (URT) (1982). The Local Government (District Authorities). Presidents' Office. Dar es Saalam. 86 pp.

URT, (2009). The Constituencies Development Catalyst Fund Act, President's Office. Dar es Salaam. 17 pp.

URT, (2011). Tanzania Open Government Partnership (OGP) Action Plan. A Draft for Consultation. President's Office. Dar es Salaam. 9 pp.

URT, (2012) The National Public Procurement Policy. Ministry of Finance. Dar es Salaam. 44 pp.

Weiss G.T (2010) Governance, Good governance and Global Governance: Conceptual and Actual Challenges. Third World Quarterly. 21 (5), 795- 814. 